\title{
STOCK PRICE BEHAVIOR AROUND CUM-DIVIDEND DATE OF INDONESIA BLUE CHIPS STOCKS
}

\author{
Eka Lavista \\ College of Economics Widya Gama Lumajang \\ *Corresponding Author:
}

\begin{abstract}
This study tests whether there are significant stock prices changes around the cum-dividend date. In particular, it examines the stock price movement of two days before and two days after the cum-dividend date. It uses an event study methodology. The population of this study are all companies in the LQ45 listed at Indonesia stock exchange for the year 2017 and the sample consists of 38 companies. Abnormal return is measured using the single index model. Results show that there are no significant abnormal returns around the cum-dividend date. In addition, there is no significant abnormal return difference between two days before and two days after the cum-dividend date. The implication of the reported findings is that investors may not obtain significant positive abnormal returns using a cum-dividend date as the trading strategy.
\end{abstract}

Keywords: dividend, cum-dividend date, abnormal return, event study

\section{A. Introduction}

In Indonesia, the decision on the amount of dividend is set up in the general meeting of shareholders (Gumanti, 2013). It means the time of dividend payment is known days before the announcement. This situation is different compared to the practices in the western countries where the management has the discretion to decide the amount of dividend. Thus, in the western countries, the investors may consider the timing of dividend payment is of high valuable that will affect their investment decision. In other words, the uncertainty about dividends payment is lower for Indonesian investors.

Companies may have different motives on when they decide to pay the dividend. One of the main reasons is the availability of money. If the company

\footnotetext{
*Corresponding Author.

e-mail: ekalavista@gmail.com
} 
has adequate cash, it may decide to disburse dividend payment. Thus, the management shall prepare for the fund availability before paying the dividend.

On the other hand, the extent of dividend can be used as a signal by the company to demonstrate the financial and performance capabilities. A good company will use dividend as a signal informing the investors that the company has relatively adequate funds. A low-quality company is assumed to be unable to mimic good quality company given inadequate funds. Capital gain orientated investors expect that the stock price of the company that pays dividend will rise. Thus, if the stock price goes up, investors will not only obtain capital gain but also generate cash dividend if they still hold the stocks up to the ex-dividend date. The company announcing an increase in dividends will experience an increase in stock prices as shown by positive changes in its cumulative abnormal returns and vice versa (Aharony and Swary, 1980). However, there is no evidence of abnormal return around the ex-dividend date in Spain (Garcia-Blandonand Martinez-Blasco, 2012) and only weak evidence among BRIC countries (Cherkasova and Petrukhin, 2017).

The current study examines the price movement around the cum-dividend date. The motivation of this study relies on our interest that most of the studies on market response to dividend policy so far are heavily directed to the presence or the absence of abnormal return on the dividend declaration date. To our knowledge, there seems to be, if not limited, no study focused on the examination of stock price changes on the last day, where shareholders will still be entitled to a dividend (cum-dividend date). Thus, the objective of this study is to examine the stock price changes, measured as the abnormal returns, around the cum-dividend date.

Using a sample of 38 blue chips companies listed in Indonesia stock exchange for 2017, the study does not find either significant abnormal returns on two days before, on the day, and two days after cum-dividend date or any significant difference between abnormal return two days before and two days after the cum-dividend date. We argue that the Indonesia capital market is efficient, at least on the semi-strong form. The remainder of the paper is organized as follows: the next section presents the hypotheses development; section three provides the description of research methods; sections four reports the findings along with the discussion. The final section concludes the paper. 


\section{B. Literature Review}

Studies on dividend policy mostly focused on the determinants of crosssectional dividend levels, i.e., dividend payout ratio or dividend yields. However, studies using event study approach are also widely practiced, in particular, the examination of the effects of dividend changes and dividend announcements on stock prices. Baker and Weigand (2015), identified that there are at least eight competing theories on dividend which have been examined in various capital markets.

A survey literature study by Baker and Weigand (2015) shows an interesting finding. The importance of cash dividends as a part of investors' total returns has declined over time. Does it mean that investors are no longer considering dividend as an important factor for stock price selection criteria? They also report that dividend policy is sensitive to numerous factors inherent in the company as well as external to the companies. In other words, the company's characteristics and market characteristics determine the level of dividends.

Previous studies tend to be directed to examine the relationship between profit changes, dividend changes, and stock price changes. However, the majority of these studies test partially. They did not attempt to specifically link these three aspects together as to be able to answer whether there was an impact of dividend payment on the stock prices around the cum-dividend date. The study of market reaction around cum-dividend date becomes interesting because logically there will be price increase before or on the cum-dividend date. Consequently, the price tends to go down afterwards.

Empirical evidence seems to confirm that the effect dividend announcement is not always the same between capital markets in the worlds. For example, Bahsir et al. (2013) concluded that investors in the Karachi Stock Exchange obtain positive returns in response to the dividend announcement. A study at Muscat Securities Market shows that dividend increases have made the stock prices to go up, while the declining dividend has led the stock prices to go down (al-Yahyaee et al., 2011). Another study shows a positive and significant relationship between cumulative abnormal returns (CAR) and the company's profitability and stock prices (Fargher and Weigand, 2009).

Nonetheless, two studies report a negative relationship between CAR and risk (Frankfurter and Wood, 2002; Bozos et al., 2011). How et al. (2011) studied 
Australian companies and found that stock prices increase at the time of dividend announcement. Yip et al. (2010) showed evidence supporting the signaling hypothesis in the Malaysian capital market. Lee et al. (2012) reported that dividend changes are strongly related to contemporary earnings changes, although the effect is weakening over the next year and largely unrelated to earnings changes for more than one year.

Isaksson and Islam (2013) examined the ex-day stock price behavior of blue-chip stocks in the US, the UK, Japan, and China). They observed that the stock price drop does not differ from the dividend amount on the ex-dividend day on the New York and Shanghai Stock Exchange. They also did not find evidence of any abnormal return and short-term trading. They documented that the stock prices fall less than the dividend amount on the Tokyo Stock Exchange, which is different, compared to the London Stock Exchange. They observed abnormal return and short-term trading around the ex-day on the Tokyo and London Stock Exchanges. Overall, Isaksson and Islam reported significant abnormal returns on the ex-dividend date.

The Indonesia studies showed conditions that are not much different from other countries. Siaputra and Atmadja (2006) and Firmansyah and Violita (2007) provided evidence that differences exist on the stock prices reaction between before and after the ex-dividend date. However, Winarno (2006) showed that the market does not react positively on the announcement of dividend increase. It indicates that market reaction to changes in dividend or dividend announcements is not always the same. Another study shows that the structure of ownership affects the dividend policy (Setiawan et al., 2016).

The theoretical explanation and empirical evidence shown above could be summarized in several main points. Firstly, the cum-dividend date becomes one of the important dates where investors will still receive dividends if they are registered as shareholders. Secondly, investors react to changes in the size of dividends. Lastly, if the investors react positively to the dividend announcement, especially the announcement relating to the increase, then the frequency of transaction around the day where the shareholder will still receive the dividend will increase. 


\section{Hypothesis}

Based on the summary above, it is clear that the investors' reactions to dividend announcements vary, whether on days around the dividend announcement, around the cum-dividend date, or the ex-dividend date. In general, there is support for signaling hypothesis theory, such as How et al. (2011) or Yip et al. (2010). Based on these findings, the hypotheses of this study are as follows:

$\mathrm{H}_{1}$ There is an abnormal return on days around the cum-dividend date $\mathrm{H}_{2}$ Abnormal return of stock differs between before, on, and after the cumdividend date

\section{Research Method}

The hypotheses of this study are tested using the event study methodology. Consequently, the abnormal returns of each company shall be computed. Figure 1 shows the time frame and data analysis estimation period employed in this study.

Estimated period (-60 days)

Two days before the event Two days after the event

EventDay

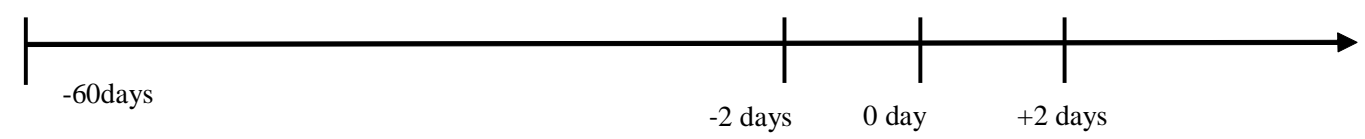

Figure 1 The Estimation Period of the Study

This study tests all the LQ45 companies that pay cash dividends in 2017. The selected companies shall meet the following criteria:

1. The company must pay the dividend for two consecutive years. This criterion is set up to ascertain that the company pays the dividend on a regular basis.

2. The company's stock must be liquid. This means the stock must be traded for at least 100 times a day and be traded in at least 150 days in a year, or a non-sleeping stock. 
Review of Management and Entrepreneurship

Volume 02, Number 01, April 2018

If the data are normally distributed, the test of hypotheses is the mean difference test. If the distribution of the data is not normal, the Wilcoxon test will be used.

\section{Results and Discussion}

A total of 38 companies out of 45 companies has met the sample determination criteria. Table 1 lists the companies examined in this study.

Table 1 List of Companies Included in the Study

\begin{tabular}{|c|l|l|l|}
\hline No. & Code & \multicolumn{1}{|c|}{ Name of Companies } & \multicolumn{1}{|c|}{ Cum Div-Date } \\
\hline 1 & AALI & Astra Agro Lestari Tbk & 20 April 2017 \\
\hline 2 & ADHI & Adhi Karya (Persero) Tbk & 17 March 2017 \\
\hline 3 & ADRO & Adaro Energy Tbk & 04 May 2017 \\
\hline 4 & AKRA & AKR Corporindo Tbk & 28 April 2017 \\
\hline 5 & ASII & Astra International Tbk & 28 April 2017 \\
\hline 6 & BBCA & Bank Central Asia Tbk & 13 April 2017 \\
\hline 7 & BBNI & Bank Negara Indonesia (Persero) Tbk & 23 March 2017 \\
\hline 8 & BBRI & Bank Rakyat Indonesia (Persero) Tbk & 22 March 2017 \\
\hline 9 & BBTN & Bank Tabungan Negara (Persero) Tbk & 24 March 2017 \\
\hline 10 & BJBR & BPD Jawa Barat dan Banteng Tbk & 05 April 2017 \\
\hline 11 & BMRI & Bank Mandiri (Persero) Tbk & 21 March 2017 \\
\hline 12 & BMTR & Global Mediacom Tbk & 07 July 2017 \\
\hline 13 & BSDE & Bumi Serpong Damai Tbk & 09 June 2017 \\
\hline 14 & GGRM & Gudang Garam Tbk & 03 July 2017 \\
\hline 15 & HMSP & H. M. Sampoerna Tbk & 05 May 2017 \\
\hline 16 & ICBP & Indofood CBP SuksesMakmur Tbk & 09 June 2017 \\
\hline 17 & INDF & Indofood Sukses Makmur Tbk & 09 June 2017 \\
\hline 18 & INTP & Indocement Tunggal Prakasa Tbk & 30 May 2017 \\
\hline 19 & JSMR & Jasa Marga (Persero) Tbk & 22 March 2017 \\
\hline 20 & KLBF & Kalbe Farma Tbk & 12 June 2017 \\
\hline 21 & LPKR & Lippo Karawaci Tbk & 31 March 2017 \\
\hline 22 & LPPF & Matahari Departement Store Tbk & 04 May 2017 \\
\hline 23 & LSIP & PP London Sumatra Tbk & 08 June 2017 \\
\hline 24 & MNCN & Media Nusantara Citra Tbk & 07 July 2017 \\
\hline
\end{tabular}




\begin{tabular}{|l|l|l|l|}
\hline 25 & MPGAS & Perusahaan Gas Negara (Persero) Tbk & 12 May 2017 \\
\hline 26 & PPRO & PP Properti Tbk & 15 March 2017 \\
\hline 27 & PTBA & Tambang Batubara Bukit Asam (Persero) Tbk & 28 April 2017 \\
\hline 28 & PTPP & PP (Persero) Tbk & 23 March 2017 \\
\hline 29 & PWON & Pakuwon Jati Tbk & 09 June 2017 \\
\hline 30 & SCMA & Surya Citra Media Tbk & 26 May 2017 \\
\hline 31 & SMGR & Semen Indonesia (Persero) Tbk & 07 April 2017 \\
\hline 32 & SMRA & Summarecon Agung Tbk & 22 June 2017 \\
\hline 33 & SSMS & Sawit Sumbermas Sarana Tbk & 29 May 2017 \\
\hline 34 & TLKM & Telekomunikasi Indonesia (Persero) Tbk & 02 May 2017 \\
\hline 35 & UNTR & United Tractors Tbk & 25 April 2017 \\
\hline 36 & UNVR & Unilever Indonesia Tbk & 04 July 2017 \\
\hline 37 & WIKA & Wijaya Karya (Persero) Tbk & 24 March 2017 \\
\hline 38 & WSKT & Waskita Karya (Persero) Tbk & 24 March 2017 \\
\hline
\end{tabular}

Source: www.eddyelly.com

Table 2 Descriptive Statistics of Abnormal Return around Cum-Dividend Date

\begin{tabular}{clccccr}
\hline No. & \multicolumn{1}{c}{ Description } & Mean & Median & Minimum & Maximum & Dev. Stand. \\
\hline 1 & Day Minus 2 & -0.0022 & -0.0022 & -0.0340 & 0.0283 & 0.0113 \\
2 & Day Minus 1 & -0.0030 & -0.0029 & -0.0530 & 0.0393 & 0.0188 \\
3 & Cum-dividend date & -0.0029 & -0.0047 & -0.0348 & 0.0397 & 0.0150 \\
4 & Day Plus 1 & -0.0071 & -0.0148 & -0.0388 & 0.1498 & 0.0317 \\
5 & Day Plus 2 & -0.0040 & -0.0030 & -0.0397 & 0.0454 & 0.0186 \\
\hline
\end{tabular}

As shown in Table 2, the mean abnormal returns for the five days around the cum-dividend date is negative. In contrast to our expectations, none of the mean abnormal returns are positive. This finding suggests that investors experience negative abnormal returns, thus meaning that investors lose their investment around the cum-dividend date. A test on whether there are significant abnormal returns on days around cum-dividend date shows that none of the mean abnormal returns are significantly different from zero. In other words, hypothesis one $\left(\mathrm{H}_{1}\right)$ is rejected at the traditional level.

Next test is based on whether there is significant difference of abnormal returns between before and after the cum-dividend date. Our test is based on a single day by day comparison. That is, day minus 2 compared with the cum- 
dividend date, the cum-dividend date with day minus 1 , the cum-dividend date with day plus 2, and two days before the cum-dividend date with two days after cum-dividend date.

Table 3 presents the results of the hypothesis testing on whether or not there are differences in abnormal returns between days around the cum-dividend date. As shown in Table 3, the results of the hypothesis testing showed no significant difference in abnormal returns between the days examined. All five pairs tested do not provide evidence that the mean abnormal returns between days being examined are not significantly different. The findings reported here indicate that, with everything else being equal, the cum-dividend is not used by the investors as an investment strategy. In other words, hypothesis two $\left(\mathrm{H}_{2}\right)$ is rejected.

Nevertheless, the evidence of no significant abnormal returns on the cumdividend and other days around the cum-dividend date (Table 2) implies that Indonesia's capital market at least is to be classified as the semi-strong efficient market (Fama, 1970). According to efficient capital market perspective, a market is said to be a semi-strong form as we are unlikely to obtain an abnormal return by relying on publicly available information. The announcement of dividend payments is a reflection of public information. In a semi-strong efficient market, public information and past stock price information cannot be used to continually gain an abnormal return.

The findings reported here are in contrast to our initial expectation that for companies included in the blue-chip stocks, the expectation of investors shall be higher than non-blue-chips companies. Our findings suggest that the price changes between companies are not too much. Interestingly, we document that all of the mean abnormal returns are negative. We are not in the capacity to argue that the blue-chip stocks are not interesting as the targets for investment. Rather, our finding might be driven by the use of the model in estimating abnormal returns.

The findings reported here, of course, are different compared to some previous Indonesian studies examining price reaction around dividend announcement (Siaputra and Atmadja, 2006; Firmansyah and Violita, 2007). However, it is consistent with Winarno (2006), who showed no significant market reaction on the announcement of a dividend increase. 
Eka Lavista / Stock Price Behavior Around Cum-Dividend Date of Indonesia Blue Chips Stocks

Table 3 Median Abnormal Returns Test Results

\begin{tabular}{|c|c|c|c|c|c|c|c|c|c|c|}
\hline \multirow{2}{*}{ Description } & \multicolumn{2}{|c|}{ M2-CD } & \multicolumn{2}{|c|}{ M1-CD } & \multicolumn{2}{|c|}{ CD-P1 } & \multicolumn{2}{|c|}{ CD-P2 } & \multicolumn{2}{|c|}{$2 \mathrm{~B}-2 \mathrm{~A}$} \\
\hline & M2 & $\mathrm{CD}$ & M1 & CD & $\mathrm{CD}$ & P1 & $\mathrm{CD}$ & P2 & $2 B$ & $2 \mathrm{~A}$ \\
\hline Mean & -0.0022 & -0.0029 & -0.0030 & -0.0029 & -0.0029 & -0.0071 & -0.0029 & -0.0040 & -0.0026 & -0.0056 \\
\hline Mean dif. & \multicolumn{2}{|c|}{0.0007} & \multicolumn{2}{|c|}{0.0001} & \multicolumn{2}{|c|}{0.0042} & \multicolumn{2}{|c|}{0.0011} & \multicolumn{2}{|c|}{0.0003} \\
\hline t-value & \multicolumn{2}{|c|}{0.245} & \multicolumn{2}{|c|}{-0.022} & \multicolumn{2}{|c|}{0.732} & \multicolumn{2}{|c|}{0.257} & \multicolumn{2}{|c|}{0.772} \\
\hline p-value & \multicolumn{2}{|c|}{0.808} & \multicolumn{2}{|c|}{0.983} & \multicolumn{2}{|c|}{0.469} & \multicolumn{2}{|c|}{0.799} & \multicolumn{2}{|c|}{0.445} \\
\hline Conclusion & \multicolumn{2}{|c|}{$\begin{array}{l}\text { There is no } \\
\text { difference }\end{array}$} & \multicolumn{2}{|c|}{$\begin{array}{l}\text { There is no } \\
\text { difference }\end{array}$} & \multicolumn{2}{|c|}{$\begin{array}{l}\text { There is no } \\
\text { difference }\end{array}$} & \multicolumn{2}{|c|}{$\begin{array}{l}\text { There is no } \\
\text { difference }\end{array}$} & $\begin{array}{l}\text { Ther } \\
\text { diffe }\end{array}$ & $\begin{array}{l}\text { is no } \\
\text { ence }\end{array}$ \\
\hline
\end{tabular}

Note: M2 is day Minus 2, M1 is day Minus 1, the CD is the cum-dividend date, P1 is day Plus 1, P2 is day Plus 2, 2B is two days before the cum-dividend date, and 2A is two days after the cum-dividend date

In this study, we employ the single index model to estimate the expected returns. Others may argue that that the single index model is too simple given the fact that we only estimate the expected return using a market index. One may also argue that the use of the capital asset pricing model (CAPM) or event match-pair model could generate better findings. However, we contend that the use of single index model employing the LQ45 index as the market portfolio is more representative for examination of companies in the LQ45 index.

\section{E. Conclusion}

This study aims to examine the presence or absence of differences in abnormal return of stocks on the days around the cum dividend date. It examines 38 blue-chip companies that paid dividends in the year 2017. The findings show that the investors do not obtain abnormal return in the days around cum-dividend date. In addition, there is no significant difference in abnormal returns between five pair-days including between before and after the cum-dividend date.

Referring to the finding shown in this study, two suggestions for the future studies holds the merit to be considered further. First, future studies may test the difference in abnormal returns and trading volume activity by comparing industries (sectors). Second, future studies may focus on samples with high trading rates around cum-dividend date to explicitly observe stocks that have high trading liquidity. 


\section{F. References}

Aharony, J. and I. Swary. 1980. Quarterly Dividends and Earnings Announcement and Stockholders' Return: An Empirical Analysis. Journal of Finance, 35(1): 1-12.

Al-Yahyaee, K.H., T.M. Pham., and T.S. Walter. 2011. The Information Content of Cash Dividend Announcements in a Unique Environment. Journal of Banking \& Finance, 35(3): 606-612.

Baker, K.E. and R. Weigand. 2015. Corporate Dividend Policy Revisited. Managerial Finance. 41(2): 126-144.

Bashir, U., S.Z.A. Shah., and M. Hussain. 2013. On the Differential Market Reaction to Dividend Announcement: Evidence from an Emerging Equity Market, Financial Assets and Investing, 3(1): 7-24.

Bozos, K., K. Nikolopoulos., and G. Ramgandhi. 2011. Dividend Signaling under Economic Adversity: Evidence from the London Stock Exchange. International Review of Financial Analysis, 20(5): 364-374.

Cherkasova, V.A. and Petrukhin, V.V. 2017. The Ex-Day Phenomenon and Share Price Performance on Emerging Markets. Journal of Corporate Finance Research, 11(1): 16-36.

Fama, E.F. 1970. Efficient Capital Markets: A Review of Theory and Empirical Work. Journal of Finance, 25(2): 383-417.

Fargher, N.L. and R.A. Weigand. 2009. Cross-Sectional Differences in the Profits, Returns, and Risk of Firms Initiating Dividends. Managerial Finance, 35(6): 509-530.

Firmansyah, R. and E.S. Violita. 2007. Analisis Pengaruh Pengumuman ExDividend Date Terhadap Abnormal Return: Event Study pada Bursa Efek Jakarta. Integrity-Jurnal Akuntansi dan Keuangan, 1(3): 249-262.

Frankfurter, G.M. and B. Wood, Jr. 2002. Dividend Policy Theories and Their Empirical Tests. International Review of Financial Analysis, 11(2):111-138. Garcia-Blandon, J. and Martinez-Blasco, M. 2012. The Ex-Dividend Day Anomaly in the Spanish Stock Market, Journal of CENTRUM Cathedra, 5(1): 102114.

How, J.C., K. Ngo., and P. Verhoeven, 2011, Dividend Initiations and Longrun IPO Performance. Australian Journal of Management, 36(2): 267-286. 
Isaksoon, A. and Md. M. Islam. 2013. The Ex-Dividend Day Price Behaviour of Blue-Chip Stock: International Evidence. Asian Journal of Finance \& Accounting, 5 (1): 73-88.

Lee, S.P., M. Isa., and W.L. Lim. 2012. Dividend Changes and Future Profitability: Evidence from Malaysia. Asian Academy of Management Journal of Accounting and Finance, 8(2): 93-110.

Setiawan, D., Bandi, L.K. Phua, and I. Trinugroho. 2016. Ownership Structure and Dividend Policy in Indonesia. Journal of Asia Business Studies. 10(3): 230-252.

Siaputra L. and A.S. Atmadja. 2006. Pengaruh Pengumuman Dividen Terhadap Perubahan Harga Saham Sebelum dan Sesudah Ex-Dividend Date di Bursa Efek Jakarta (BEJ). Jurnal Akuntansi dan Keuangan, 8 (1): 71-77.

Winarno, A. 2006. Hubungan Pengumuman Dividen Meningkat Dengan Reaksi Pasar Modal pada Perusahaan Manufaktur yang Go Public di BEJ (Pengujian Efisiensi Pasar Bentuk Setengah Kuat Secara Keputusan). Jurnal Ekonomi dan Manajemen, 7 (1): 117-127.

Yip, P.P., M. Isa, G.W. Kester. and S.P. Lee. 2010, Share Price Reaction to Dividend Announcements and The Interaction with Earnings Announcements in the Malaysian Stock Market. Asian Journal of Business and Accounting, 3(2): 101-120. 
Review of Management and Entrepreneurship

Volume 02, Number 01, April 2018 